\title{
Diskriminasi Terhadap Wni Keturunan Tionghoa Terkait Kepemilikan Tanah di Yogyakarta
}

\section{Brilian satrio pamungkas ${ }^{1}$}

Ilmu Pemerintahan, Universitas Sultan AgengTirtayasa briliantsp@gmail.com

\section{Febrio Elfianta ${ }^{2}$}

IlmuPemerintahan, Universitas Sultan AgengTirtayasa febriofianta@gmail.com

\section{Kintan Anindita Zulfana ${ }^{3}$}

Ilmu pemerintahan,Univeristas Sultan AgengTirtayasa kinkintanaz@gmail.com

Tanti Sabila ${ }^{4}$

Ilmu pemerintahan,Univeristas Sultan AgengTirtayasa Tantisabila12@gmail.com
E-ISSN (2721-0642)

Recieved:

January 12021

Revised:

March 182021

Accepted:

April 142021

\section{Doi Number}

https://doi.org/10.37950/ijd.v3i1.76

\begin{abstract}
This scientific journal writing aims to analyze the land policy established by the Yogyakarta Special Region government regarding land rights ownership for Indonesian citizens of Chinese descent. The enactment of the UUAP in Jogja resulted in that individuals with Indonesian citizenship status were allowed to pocket or hold ownership rights to land. However, this is very inversely proportional to reality, first implementing the Deputy Governor's Instructions which made it impossible for Indonesian citizens of Chinese descent to own land rights in Jogja. The local government only allows Indonesian citizens of Chinese descent to only be allowed as use rights, building use rights, and business use. The Yogyakarta Regional Government seems to discriminate against its citizens, especially those of Chinese descent. This situation has made many Indonesian citizens of Chinese descent cast strong protests over the ownership of land rights for their groups to the local government
\end{abstract}

Keywords: citizenship, restriction on the acquisition of rights, land ownership in Yogyakarta

\begin{abstract}
Abstrak
Penulisan jurnal ilmiah ini bertujuan untuk menganalisis kebijakan pertanahan yang ditetapkan oleh Pemerintah Daerah Istimewa Yogyakarta mengenai kepemilikan hak atas tanah bagi warga negara Indonesia keturunan Tionghoa. Dengan berlakunya UUAP di Jogja, warga negara Indonesia diperbolehkan mengantongi atau memiliki hak kepemilikan atas tanah. Namun hal ini sangat berbanding terbalik dengan kenyataan, pertama melaksanakan Instruksi Wakil Gubernur yang tidak memungkinkan warga negara Indonesia keturunan Tionghoa memiliki hak atas tanah di Jogja. Pemerintah daerah hanya mengizinkan warga negara Indonesia keturunan Tionghoa untuk hanya diperbolehkan sebagai hak pakai, hak guna bangunan, dan
\end{abstract}


guna usaha. Pemerintah Daerah Yogyakarta terlihat melakukan diskriminasi terhadap warganya, terutama yang keturunan Tionghoa. Situasi ini membuat banyak warga Indonesia keturunan Tionghoa melayangkan protes keras atas kepemilikan hak atas tanah bagi kelompoknya kepada pemerintah daerah.

Kata kunci: kewarganegaraan, pembatasan perolehan hak, kepemilikan tanah di Yogyakarta

\section{Pendahuluan}

Kewarganegaraan Indonesia telah jelas tercantum dalam Undang-Undang No. 12 Tahun 2006. Namun jauh sebelum diberlakukannya UU tersebut, di Indonesia terdapat pengklasifikasian mengenai penduduknya yang masih mengadopsi peraturan di zaman Hindia Belanda. Sebab pada saat itu Indonesia belum mampu menghasilkan produk hukum yang mengatur mengenai kependudukan. Penggolongan tersebut dimaksudkan untuk mengatur bagi tiap tiap golongan sekaigus untuk mengatur sistem hukum pertanahannya. Pada saat itu terdapat tiga kelompok atau golongan penduduk yaitu penduduk golongan Eropa yang didalamnya termasuk Bangsa Belanda dan juga orang-orang yang datang dari benua Eropa, bangsa Jepang serta mereka yang berasal dari negara yang menganut hukum kekeluargaannya serupa dengan hukum kekeluargaan Belanda. Golongan kedua ialah Timur Asing yang dipecah menjadi dua golongan lagi, Timur Asing Cina yang menganut pada hukum perdata barat dan Timur Asing bukan Cina yang menganut hukum adat masing masing. Golongan ketiaga ialah Bumiputra, yang mana golongan ini adalah orang Indonesia asli tanpa campuran golongan lain. Aturan hukum peraturan ini tentunya sudah tidak berlaku lagi di Indonesia.

Namun, walaupun peraturan tersebut sudah tidak berlaku lagi, tetap saja masih terdapat pembedaan atau diskriminasi kewarganegaraan anatara WNI dengan WNI Non Pribumi yang terjadi di Daerah Isimewa Yogyakarta. Diskriminasi tersebut terkait dengan larangan hak kepemilikan terhadap warga negara Indonesia keturunan Cina atau Tionghoa. Di Jogja hak kepemilikan tanah diperuntukan pribumi, sedangkan untuk WNI non Pribumi khususnya Tionghoa tidak boleh memiliki tanah mereka hanya diperbolehkan akan hak guna bangunan saja. Dalam UUPA (Peraturan Dasar Pokok-Pokok Agraria) tercantum Warga Negara Indonesia tunggal dan Warga Negara Asing. Yang mana disebutkan segenap Warga Negara Indonesia, mereka berkuasa menyandang kewenangan yang sejajar guna memeroleh hak atas kepemilikan tanah, hak guna bangunan, hak untuk usaha, sewa, bahkan hak untuk memungut hasil hutan baik untuk dirinya sendiri maupun keluarganya. Sedangkan hak pakai serta hak sewa diperuntukan untuk WNA.

Walaupun sudah ada peraturan yang yang sah terkait kepemilikan tanah bagi warga negara Indonesia termasuk WNI keturunan Tionghoa didalamnya, namun realitanya merka dilarang memiliki hak atas tanah. Pemerintah Daerah Yogyakarta seolah-olah mendiskriminasi terhadap warganya terkhusus warga keturunan Tionghoa. Memang ini semua tidak terlepas dari historis kepemilikan tanah di Jogja. Tanah milik sultan dan Paku Alam merupakan tanah yang sebagian besar dimiliki daerah kota pelajar tersebut. Terdapat juga tanah magersari dimana tanah tersebut diberikan oleh raja kepada rakyatnya untuk dapat dikelola dan ditempati. 
Yogyakarta sebagai kota istimewa memang diberi wewenang khusus untuk merancang prosedur pertanahan di kawasanya sendiri. Sesuai dengan pasal 4 yang tertuang dalam UU No. 3 Tahun 1950 tentang Pendirian Daerah Istimewa Yogyakarta yangmana memfatwakan kepeda pemda setempat untuk mengurus urusan termasuk urusan agraria. Secara detail kebijakan pertanahan menegenai pembatasan hak milik atas tanah akan WNI keterunan Tionghoa, bersumber dari Kepala Daerah Istimewa Yogyakarta melahirkan sebuah Intruksi yang diwakili oleh Wakil Kepala DIY (Wagub) yang tertuang dalam Surat No K.898/I/A/1975 mengnai penyamaan kebijkan pelimpahan hak atas tanah kepada WNI non Pribumi. Yangmana isi arahan itu mengharuskan WNI non Pribumi untuk melepaskan hak milik atas tanahnya yang kemudian setelah dilepaskan WNI non Pribumi mengajukan penawaran kepada pemerintah setempat untuk memperoleh hak lain. Terlihat jelas bahwa kesenjangan perlakuan terhadap WNI non Pribumi dengan WNI Pribumi yang berdiam di kota pelajar tersebut.

\section{Kerangka Teori \\ Diskriminasi}

Sebagaimana kita ketahui bahwa negara indoneseia adalah negara yang kaya akan keanekaragaman buday,adat,bahasa, ras atau etnis, dan lain-lain. akan tetapi adanya keanekaragaman tentunya konsekuensi adanya keanekaragaman tidak dapat dihindarkan seperti diskirimanasi yaitu sebuah tindakan yang tidak sesuai dengan norma yang ada di masyarakat yang merugikan satu orang atau kelompok oleh orang atau kelompok lain yang dimana hal ini selaras denagn pendapat dari Theodorson menngungkapkan diskriminasi sebagai perlakuan tidak balance terhadap kalangan ataupun kelompok bersumber pada suatu, umumnya bertabiat kategorial, ataupun atributatribut khas, semacam bersumber pada ras, kesukubangsaan, agama, ataupun kenaggotaan kelas- kelas sosial. Bagi Brigham, diskriminasi merupakan perlakuan secara berbeda sebab keanggotaanya dalam sesuatu kelompok etnik tertentu. Kelompok etnik tersebut antara lain merupakan suku bangsa, bahasa, adat istiadat, agama, kebangsaan, serta yang lain. Jadi bisa disimpulkan kalau diskriminasi merupakan suatu pembedaan perlakuan satu orang dengan orang lain ataupun sekelompok/ organisasi dengan yang lain baik kalangan ataupun suku, corak kulit, ekonomi, generasi, perbandingan tipe kelamin, agama, budaya serta lain- lain. perihal tersebut terjalin sebab terdapatnya pihak yang dominan lebih memahami dalam sesuatu perihal disuatu ruang lingkup pihak minoritas.

\section{Hak Kepemilikan tanah}

Secara konsep hukum hubungan manusia dengan benda disebut hak yang berarti benda tersebut dimiliki oleh seseorang, hal ini serupa dengan hak atas kepemilikan tanah dimana apabila seseorang telah menduduki atau menguasai suatu tanah atau wilayah secara hukum maka seseorang tersebut memiliki hak atas tanah atau wilayah tersebut Hak kepemilikan tanah ialah hak kemampuan atas tanah yang berisikan kewajiban ataupun larangan serta wewenang untuk seorang yang memegang ataupun pemegang, supaya melaksanakan suatu yang menimpa tanahnya. Perihal ini diperkuat dengan terdapatnya peraturan pasal 16 ayat 1 UUPA tentang macam- macam hak atas kepemilikan tanah yaituu hak kepunyaan, hak guna bangunan(hgb), hak guna usaha(hgu), hak sewa hak membuka tanah, hak hasil hutan, 
serta hak- hak lain yang tidak tercantum dalam hak- hak tersebut di atas yang hendak didetetapkan dengan undang- undang, dan hak- hak yang sifatnya sedangkan bagaikan yang diucap dalam Pasal.

\section{Metode Penelitian}

Metode penelitian merupakan cara untuk menentukan sebuah permasalahan. Sebuah metode penelitian bisa dikatakan pisau analisa guna menjawab dan mengungkap suatu permasalahan. Pada penelitian penelitian kami ini menggunakan pemaparan dengan menggunakan studi literatur yang berasal dari sumber-sumber online. Adapun sumbernya seperti buku dan jurmal online hingga web yang dirasa berkaitan dengan penelitian ini.

Fokus penelitian kali ini adalah : hak atas tanah bagi warga negara Indonesia keturunan Tionghoa yang ditetapkan oleh Pemerintah Daerah Istimewa Yogyakarta. Lokasi penelitian ini di Daerah Istimewa Yogyakarta. Pengumpulan data pada penelitian ini adalah dilakukan dengan studi literature.

\section{Hasil dan Diskusi}

Daerah kerajaan atau bisa pula disebut daerah swapraja itulah sebutan bagi Daerah Istimewa Yogyakarta termasuk didalamnya Raja Sultan Hamengkubuwono serta Kadipaten Paku Alam. Sebelum Indonesia merdeka, semua tanah di Jogja merupakan milik raja. Rakyat hanya diizinkan untuk memakai saja tidak untuk memilikinya. Terlebih mereka diharuskan menghibahkan sebagian hasil tanahnya (tanah pertanian) kepada raja atau melaksanakan kerja paksa jika tanah tersebut tanah pekarangan. Namun setelah merdeka aturan tersebut tidak lagi berlaku.

Jika menilik dalam hukum agraria atau Diktum keempat UUPA, yang tadinya tanah-tanah dibawah kuasa oleh mantan kesultanan beralih selaku tanah yang dikuasai oleh negara. Sedangkan tanah yang dikuasai oleh Sultan dan Paku Alam menjadi tanah milik keluarga besar. Diberlakukannya UUPA di Jogja menghasilkan bahwa perorangan yang berstatus WNI diperbolehkan untuk mengantongi atau menyandang hak milik akan tanah. Namun aturan tersebut sangat berbanding terbalik dengan realita, terlebih dengan diterapkannya Intruksi Wagub yang ditetapkan membuat WNI keturunan Tionghoa tidak bisa memiliki hak milik atas tanah di Jogja. Pemerintah setempat sekedar membolehkan WNI keturunan Tionghoa tersebut hanya di izinkan untuk dapat memiliki Hak Guna Bangunan (HGB) yaitu hanya sebagai hak pakai, hak guna bangunan, serta hak guna usaha.

Dari berbagai warga non pribumi, mereka yang paling menonjol menolak dan menentang intruksi wakil gubernur 1975 yaitu mereka yang merupakan warga non pribumi keturunan Tionghoa. Jika melihat kebelakang, berdasarkan historisnya, pelarangan kepemilikan tanah bagi mereka yang bukan warga asli pribumi termasuk mereka keturunan Tionghoa di Daerah Istimewa itu disebabkan oleh adanya historis mengenai persengkokolan cina dengan penjajahan Belanda pada saat itu. Berdasarkan kerjasama itu, Kesultanan Yogyakarta awalnya memiliki rencana untuk melakukan pemindahan warga etnis Tionghoa keluar dari Jogja dengan memberlakukan Undang-Undang tertentu. Karena saat itu pemerintah Belanda lebih menganak tirikan pribumi yang mana dalam hak ekonominya para pedagang pribumi dan santri diberikan kepada mereka etnis Tionghoa dengan lebih luas.

Pada masa penjajahan Belanda itu pula, warga asli diwajibkan membayar pajak yang dimana penarikan pajak tersebut dilakukan oleh mereka etnis Tionghoa. 
Dominasi ekonomi orang Tionghoa ini mampu menguasai pangeran dan kerajaan di Nusantara, hingga bisnis mereka (etnis Cina) banyak menempati berbagai sektor mulai dari media, barang usaha, perdagangan dan sebagainya. Pada dasarnya, tidak hanya faktor sejarah saja melainkan memang tidak dapat dipisahkan bahwa memang mereka keturunan Tionghoa mempunyai dominasi ekonomi yang kuat dalam hal usaha perdagangan. Mereka etnis Cina, memang populer dengan bakat dalam berdagang yang mana memang ditopang oleh kongsi-kongsi dagang, serta kemampuan mereka dalam membuat jaringan-jaringan kelembagaan yang mumpuni terhadap tekanan kapitalis lokal. Di zaman yang semakin maju, etnis Tionghoa di Jogja mampu menguasai kepemilikan tanah sebagai tempat mereka menjalankan bisnisnya. Dengan itu, dalam melindungi tanah milik pribumi dari penguasaan etnis Tionghoa, diberlakukannya pelarangan kepemilikan tanah untuk mereka yang berstatus sebagai non pribumi. Dengan dibuatnya Undang-Undang No. 5 Tahun 1960 mengenai Peraturan Dasar Pokok Pokok Agraria (UUPA) yang mengatur mengenai kepemilikan, pengontrolan, tatanan serta terkait usaha pertanahan.

Pada dasarnya UUPA 1960 yang pada awalnya mempunyai tujuan transormatif yang mengarah pada kondisi struktur kelas kepemilikan tanah ini justru hadir di dalam kondisi yang masih dalam masalah kewarganegaraan bahkan mengarah pada diskriminasi berbasis rasial dan sampai saat ini masih menunjukkan kekerasan dalam wujud regulasi, kekuasaan dan legitimasi kepada mereka yang merupakan keturunan tionghoa. Dengan demikian, Pemisahan akan golongan satu dengan golongan penduduk atas kepemilikan tanah diatas berimplikasi dalam peraturan khusus antar golongan akan tanah yaitu adanya pelarangan pengasingan tanah dimana tidak diperbolehkannya menjual tanah milik masyarakat Indonesia kepada orang yang bukan masyarakat asli Indonesia. Dalam perkembangannya, peraturan yang terkesan membedakan itu menjadi pisau yang tajam yang mana awalnya dibuat untuk memberikan perlindungan dan kesejahteraan bagi masyarakat pribumi namun menjadi sebuah perlakuan yang mendiskriminasi kelompok tertentu. Keadaan tersebut membuat WNI keturunan Tionghoa banyak melayangkan protes atas kepemilikan hak tanah bagi kelompoknya. Bahkan sebagian dari mereka membentuk sebuah komunitas dan ikut bergabung dalam Gerakan Anak Negeri Anti Diskriminasi (GRANAD). Gerakan tersebut berupaya untuk mencabut kebijakan pertanahan Pemda DIY yang mereka anggap kebijakan tersebut sebagai perlakuan diskriminasi terhadap WNI keturunan Tionghoa atas akses kepemilikan hak tanah di Jogja.

Penolakan atau protes akan kebijakan itu muncul dari mereka yang merupakan keturunan Tionghoa. Baru-baru ini layangan gugatan salah satunya adalah ajuan permohonan kepada MK terkait keistimewaan DIY dalam melakukan pelarangan kepemilikan tanah bagi orang keturunan Tionghoa, untuk meninjau kembali hal tersebut. Karena menurut penuturan salah satu mahasiwa Universitas Gajah Mada tersebut, diberlakukannya pasal sebagaimana intuksi Wagub DIY 1975 tersebut memunculkan adanya perbuatan diskriminasi atas ras dana tau suku kepada WNI yang merupakan keturunan etnis Cina, karena ketidakmungkinan dalam memiliki ha katas tanah di Jogja. Gugatan sebelumnya juga hadir dari seorang warga Indonesia yang merupakan keturunan Tionghoa bernama Handoko yang melakukan gugatan yang sama seperti mahasiswa sebelumnya yaitu terhadap intrukssi Wakil Kepala DIY tahun 1975 mengenai Penyeregamaan kebijakan pemberian Hak atas Tanah utuk seorang warga non pribumi kepada Peradilan Tata Usaha Negara di Jogja. Namun 
pengajuannya tersebut tidak bisa dilanjutkan karena alasan bahwa intruksi tersebut bukanlah sebuah diskresi. Tidak hanya berhenti pada permohonan tersebut, Handoko saat itu juga mengajukan permohonan untuk pengujian kembali materi intruksi yang sama kepada MA untk perkara No 13 tahun 2015, namun menunjukkan hasil yang sama yaitu penolakan dari MA. Gerakan Nasional Anti Diskriminasi pada 2011 memberikan surat kepada presiden untuk tidak adanya lagi diskriminasi dalam pengurusan terkait sertiikat tanah bagi warga negara non pribumi, namun lagi-lagi ditempis oleh Pemerintah Daerah Jogja. Komnas HAM juga menyatakan bahwa intruksi 1975 bertentangan dengan HAM, bagaimanapun tidak semua keturunan cina memiliki dominasi ekonomi.

Sampai pada tahun 2018, Ombudsman RI di Jogja mengatakan yaitu ada diterapkannya Intruksi 1975 merupakan praktik maladministrasi dan perbuatan diskriminatif kepada pelayanan urusan tanah. Namun, laporan ORI di Jogja itu belum mendapatkan jawaban dan gugatan tersebut menurut penuturan sultan Yogyakarta masih belum ada jawaban apakah akan dibuat upaya hukum atau tidak. Terlepas dari hal diatas, bagaimanapun, pelarangan kepemilikan tanah bagi warga non pribumi terutama etnis Tionghoa di DIY menunjukkan bahwa ada perlakuan diskriminasi yang bertentangan dengan Undang-Undang NKRI Tahun 1945 terutama pasal 28D (1) tentang kesamaan hak atas pengakuan, perlindungan, jaminan serta kepastian hukum yang seadil-adilnya.

\section{Kesimpulan}

Pada penelitian mengenai Diskriminasi Terhadap WNI Keturunan Tionghoa Terkait Kepemilikan Tanah di Yogyakarta dapat disimupulkan bahwa semua tanah di Jogja merupakan milik raja yang dimana masyarakat hanya diizinkan untuk memakai saja tidak untuk memilikinya. Namun peraturan tersebut berubah ketika munculnya sebuah UUPA sebagai penetapan Hak Milik atas tanah yang dapat dimiliki oleh WNI di Indonesia, sebagai bentuk pengimplementasian dari UUPA yang di buat oleh pemerintah, maka pemerintah Yogyakarta memberlakukan UUPA di daerah Yogyakarta termasuk dari kepemilikan hak atas tanah bagi WNI di Yogyakarta apapun itu keturunannya, yang dimana hasil dari UUPA di Yogyakarta bahwa perorangan yang berstatus WNI diperbolehkan untuk mengantongi atau menyandang hak milik akan tanah, namun itu semua hanyalah ilusi yang dimana ada sebuah problematika yang ada bagi WNI dengan keturunan Tionghoa dengan diterapkannya Intruksi Wagub yang ditetapkan membuat WNI keturunan Tionghoa tidak boelh meiliki tanah di Jogja.

Maka dengan keadaan tersebut membuat WNI keturunan Tionghoa banyak melayangkan protes atas kepemilikan hak tanah bagi kelompoknya. Bahkan sebagian dari mereka membentuk sebuah gerakam. Gerakan tersebut berupaya untuk mencabut kebijskan pertanahan Pemda DIY yang mereka anggap kebijakan tersebut sebagai perlakuan diskriminasi terhadap WNI keturunan Tionghoa atas akses kepemilikan hak tanah di Yogyakarta. Terlepas dari hal diatas, bagaimanapun, pelarangan kepemilikan tanah bagi warga non pribumi terutama etnis Tionghoa di DIY menunjukkan bahwa ada perlakuan diskriminasi yang bertentangan dengan Undang-Undang NKRI Tahun 1945 terutama pasal 28D (1) tentang kesamaan hak atas pengakuan, perlindungan, jaminan serta kepastian hukum yang seadil-adilnya. Dan apabila meilhat dari praktik yang di lakukan pemerintah Yogyakarta akan Hak Kepemilikan tahan di Yogyakarta perlu adanya sebuah perubahan dengan cara maka 
perlu segera dicabut Instruksi Wakil Gubernur Daerah Istimewa Yogyakarta No.K. 898/I/ A/1975 dimana tidak seharunya ada perbedaan antara WNI asli dengan WNI keturunan Tionghoa.

\section{Tentang Penulis}

Brilian Satrio Pamungkas merupakan mahasiswa dan mahasiswi yang sedang menempuh gelar sarjana Ilmu Pemerintahan di Universitas Sultan Ageng Tirtayasa, Serang, Banten.

Febrio Elfianta merupakan mahasiswa dan mahasiswi yang sedang menempuh gelar sarjana Ilmu Pemerintahan di Universitas Sultan Ageng Tirtayasa, Serang, Banten.

Kintan Anindita Zulfana merupakan mahasiswa dan mahasiswi yang sedang menempuh gelar sarjana Ilmu Pemerintahan di Universitas Sultan Ageng Tirtayasa, Serang, Banten.

Tanti Sabila merupakan mahasiswa dan mahasiswi yang sedang menempuh gelar sarjana Ilmu Pemerintahan di Universitas Sultan Ageng Tirtayasa, Serang, Banten.

\section{Ucapan Terimakasih}

Terima kasih kami ucapakan kepada Tuhan Yang Maha Esa serta pihak-pihak yang terlibat dalam penyusunan artikel jurnal ilmiah ini.

\section{Referensi}

Andriani, Mira Norvana. (2017). Kepemilikan Hak Atas Tanah Bagi Orang Asing Di Indonesia. Jurnal Law Reform Program Studi Magister Ilmu Hukum Volume 13, Nomor 2, Universitas Diponegoro

Annafle.K., Nurmandi .A. (2016). Kelembagaan Otonomi Khusus (Otsus) Dalam Mempertahankan Nilai-Nilai Kebudayaan Di Provinsi Daerah Istimewa Yogyakarta. Jurnal Ilmu Pemerintahan Dan Kebijakan Publik. 3(2). 305-337.

Anggraeni .D.T.2012. Interaksi Hukum Lokal Dan Hukum Nasional Dalam Urusan Pertanahan Di Daerah Istimewa Yogyakarta. Jurnal Rechtsvinding, JanuariApril.1(1). 53-73.

Assa Marybella,Y., Mawuntu J Ronald., Waha Caecilia J. J.2020. Kajian Tentang Hak Atas Kepemilikan Tanah Terhadap Etnis Tionghoa Menurut Perspektif Hak Asasi Manusia. 8(3).39-49

Dwiyansany Shenita, Listiya Wardhani L.T.A. 2019. Sistem Pertanahan Keraton Yogyakarta Sebagai Daerah Otonomi Khusus. Jurnal Pembangunan Hukum Indonesia.1(2).226-235.

Dwivianto, Bakti Putra. (2016). Pengaruh Kebijakan Mengenai Etnis Tionghoa di Indonesia era Pemerintahan Abdurrahman Wahid terhadap Hubungan Bilateral Indonesia dan Tiongkok. Jurnal Analisis Hubungan Internasional, Vol. 5 No. 2 Universitas Airlangga 
Hadi, Usmam.(2019). Ada Sejarah, Kenapa WNI Nonpri Tak Boleh Punya Tanah Di Yogya.

Irawan 1.R.A.(2016). PERLINDUNGAN HUKUM TERHADAP WARGA NEGARA INDONESIA NON-PRIBUMI UNTUK MEMPEROLEH KEPASTIAN HAK MILIK. Jurnal cakrawala hukum .7(2). 247-255

Juditha, Christiany.(2015). Stereotip dan Prasangka dalam Konflik Etnis Tionghoa dan Bugis Makassar. Jurnal ILMU KOMUNIKASI. VOLUME 12, NOMOR 1: 87-104

Lestarini, ratih.(2018). Kebijakan Pertanahan Bagi Wni Keturunan Tionghoa Di Yogyakarta: Diskrimasi Atau Diskriminasi Positif. Jurnal Hukum \& Pembangunan,Januari-maret, 48(1).48-56.

Pandamdari, Endang.(2018). Mengkritisi Diskriminasi Pemilikan Tanah Di Provinsi Daerah Istimewa Yogyakarta. Jurnal Hukum Dan Pembangunan Hukum.1(1).

Prasetyo yudi. (2015). SEJARAH KOMUNITAS TIONGHOA DI YOGYAKARTA 1900-1942. Jurnal edukasi. Volume 1. 19-25

Prikasetya, Gratianus.(2018). Intergentiele Grondenregel Dalam Hukum Antar Tata Hukum Intern Terkait Kepemilikan Hak Atas Tanah Bagi Wni Keturunan Tionghoa Di Wilayah DIY. Jurnal rechtsvinding, Agustus. 7(2).261-282.

Sugiyono. 2015. Metode Penelitian Pendidikan Pendekatan Kuantitatif, Kualitatif, dan R\&D. Bandung: Alfabeta.

Sumanto, Listyowati, 2013, Pembatasan Pemilikan Hak Atas Tanah Oleh Orang Asing dan Badan Hukum Asing (Studi Perbandingan Indonesia-Turki), Jurnal Hukum Prioris, Vol.3 No.3

Winarni Retno,Hudayah Nur.(2014). Pengaruh Kebijakan Pemerintah Indonesia Terhadap Kehidupan Etnis Tionghoa Di Bidang Politik, Sosial Budaya,Dan Ekonomi Di Kabupaten Jember Dari Zaman Orde Lama Sampai Zaman Reformasi Pada Tahun 1998-2012. Jurnal Ilmu Budaya Dan Media. 2(2). 19-25 